\title{
Kirke, opera og stormoske Retskulturelle overvejelser over monumentalarkitektur
}

\author{
Hanne Petersen professor, dr.jur., Center for Retskulturelle Studier, Juridisk Faktultet, \\ Københavns Universitet ${ }^{1}$
}

Det er velkendt at Københavns opera, der blev overdraget til byen i 2004 som en gave fra nationens rigeste og mest magtfulde mand, skibsreder Mærsk Mc-Kinney Møller, ligger på den såkaldte Amalienborg akse. Det er også velkendt at netop denne placering var afgørende for giver. Operaen skulle placeres netop dér, ellers ville der ikke blive nogen opera finansieret af AP Møller og Chastine Mc-Kinney Møller Fonden. Byggeriet var i flere år et af de mest omdiskuterede byggerier i København.

Ved årtusindets begyndelse i år 2000 påbegyndtes byggeriet af dette monumentalarkitektoniske bygningsværk i København på en akse, der går fra Marmorkirken - eller Frederikskirken, som den rettelig hedder - over Amalienborg Slotsplads og Amaliehaven (også doneret af AP Møller Fonden). Man kunne kalde det en 'enevældens akse'. Det er en akse, der kan siges at symbolisere en statsform og en retskultur præget af førmoderne styreformer, hvor statsmagterne ikke er adskilt, og retten gives af kongen.

Det er også velkendt at byggeriet af en moske i København i Njalsgade igennem en årrække har givet anledning til megen offentlig debat. Der har siden 1981 været tale om et byggeri af en moske på Amager, som imidlertid endnu ikke er blevet realiseret. I foråret 2010 vedtog Københavns socialdemokratiske ledede Borgerrepræsentation at godkende en lokalplan, der tillader ombygningen af et muslimsk kulturcenter på Vibevej i Nordvestkvarteret til en shia-muslimsk moske med blå kuppel og 32 meter højre minareter. Byggestilen ser for en ukyndig ud til at lægge sig op ad forventninger til en 'traditionel' moské. Der er tale om en bygning hvis størrelse og placering er langt mindre markant end Operaens, og som vil være langt mindre bekostelig. Den forventes finansieret for midler fra udenlandske donorer angiveligt bl.a. fra Iran. Byggeriet af denne såkaldte 'stormoske' har ført til en del medieomtale og kritik, både mod byggeriet i sig selv, imod forslag til eventuelle placeringer, imod byggeriets udformning - især minareterne - og imod kilderne til dets finansiering. Behandlingen af byggesagen har så vidt vides fulgt normale demokratiske spilleregler. Ikke desto mindre opleves dette byggeri - også - som en udfordring af den retskultur, der har domineret det danske samfund.

Jeg postulerer i denne artikel at moskebyggeriet kan forstås som en del af en Nordvest-akse, der kan siges at symbolisere fremvæksten af en post-national og post-sekulær retskultur, hvor religiøse og sekulære normer ikke længere er klart adskilte, og hvor hverken religiøse, retlige eller andre normer primært er nationale, men i højere grad transnationale - til dels afhængigt af hvilke normfællesskaber, der er tale om. Arkitektur og ikke mindst monumentalarkitektur er fysisk lokalt forankret, men idemæssigt globalt inspireret og udtryk for fremherskende normer om hvad der udtrykker prestige og magt. Disse normer spiller sammen med og spiller ind på de retskulturer, de er del af. Arkitektoniske værker - faktiske bygninger - kan således tolkes som 'retskulturelle repræsentationer', og igennem denne fremstilling og tolkning kan man undersøge retskulturers udtryk og ændringer. Jeg har i denne artikel undersøgt primært operaen i København og planerne om en såkaldt 'stormoske' og de 'akser' de indgår i for at undersøge, om og i givet fald hvordan de kan forstås som udtryk for en retskultur i forandring $\mathrm{i}$ en dansk kontekst $\mathrm{i}$ det 21. århundrede. Jeg indleder artiklen med en diskussion af retskulturbegrebet og begrebet monumentalarkitektur for derefter at gå videre til at undersøge opera og Amalienborg-akse overfor stormoske og Nordvest-akse. Jeg afslutter med nogle korte overvejelser over post-national retskultur og demokratiudvikling. 


\section{Retskultur i sammenhæng og i forandring}

Den norske konservative politiker, retsvidenskabsmand og professor, Francis Hagerup, udgav i 1919, hvor han var Norges ambassadør i København en lille bog om ret og kultur, hvor han skriver:

„Den følgende fremstilling hviler paa den af videnskaben for længst vundne erkjendelse, at ligesom retten paa den ene side selv er et kulturfænomen, saaledes staar den paa den anden side i vexelvirkning med alle de andre elementer i kulturudviklingen, d.e. med alle de økonomiske, politiske, sociale etiske og intellektuelle strømninger, som bestemmer denne." ${ }^{\prime 2}$

Francis Hagerup skrev om perioden fra 1814-1914 - altså perioden efter den Franske Revolution og Napoleonskrigene - en periode som netop var meget præget af denne revolution, og dens ændring af de økonomiske, politiske og intellektuelle strømninger.

Knap tyve år senere - i 1936-37 opholdt den tyske socialdemokratiske tidligere justitsminister og retsvidenskabsmand, Gustav Radbruch, sig ved University College i Oxford. Han var blevet frataget sit professorat i Tyskland efter Hitlers magtovertagelse i 1933 og vedtagelsen i april 1933 af Gesetz zur Wiederherstellung des Berufsbeamtentums (loven om retablering af embedsmandsvæsenet), der primært men ikke kun udelukkede jøder fra offentlig tjeneste. Under sit ophold skrev han en lille bog om ånden i den engelske ret, Der Geist des englischen Rechts. På grund af forholdene i Tyskland kunne den først udkomme i 1946 og blev revideret inden. Radbruch blev efter 2. verdenskrig kendt for den såkaldte 'Radbruchske formel'. Den indeholder i grove træk en kritik af den positivistiske forståelse af retten 'Gesetz ist Gesetz' eller 'lov er lov og lov skal holdes,' der forudsætter at dommeren ubetinget skal følge loven også i tilfælde, hvor indholdet af loven er klart i strid med retfærdigheden. Han skrev en lille artikel, der er blevet betegnet som en af det 20. århundredes mest indflydelsesrige med titlen 'Gesetzliches Unrecht und übergesetzliches Recht' (Lovmæssig uret og ret over loven). ${ }^{3}$ Denne diskussion er især knyttet til de tyske erfaringer med sammenbrud af først den monarkiske militærstat efter 1. verdenskrig og derefter den ustabile Weimarrepubliks opløsning i 1933, og endelig sammenbruddet af Hitlerstaten i 1945. Denne udvikling har i en tysk sammenhæng stillet langt større spørgsmålstegn ved en moderne retspositivisk retskultur, hvor loven har den ubetinget højeste status, end i andre kontinentaleuropæiske retskulturer.

Radbruch skriver i bogen om den engelske rets ånd, at den er præget af, at det engelske parlament er udviklet direkte videre fra den middelalderlige stænderstat, mens denne stænderstat på kontinentet blev afløst af enevæl- den, og først derefter af den konstitutionelle stat. Den engelske retskultur er langt mere præget af empirisme og induktion end den kontinentale. ${ }^{4}$ Han citerer en engelsk dommer Sir Henry Slesser for i 1946 at skrive, at den engelske Common Law i sin oprindelse er et kristent retssystem, og et enestående bidrag til den kristne kultur. Også i en engelsk sammenhæng understreges her den historisk nære sammenhæng mellem ret og religion og religiøse og retlige værdier og perspektiver. ${ }^{5}$ Radbruch mener, at den engelske retstænkning er langt mere virkelighedsnær end den kontinentale retstænkning. Engelsk retskultur er præget af en bekræftelse af gældende ret (gældende Common Law) ikke gældende lov, og ses som en værdividenskab.

Radbruch forstår den amerikanske retskultur som en videreudvikling af den engelske, men med større vægt på lovgivning. Den amerikanske retshistoriker, Lawrence Friedman, skrev i 1969 en meget berømt artikel om retskultur og social udvikling, hvor han sondrede mellem professionel eller intern retskultur og en folkelig retskultur (popular culture). ${ }^{6}$ Han definerede senere populærkulturen, eller den eksterne retskultur som „de ideer, værdier, forventninger og holdninger til retten og retlige institutioner, som offentligheden eller dele af offentligheden har".7 'Mandarinkulturen' som han nu kalder den interne retskultur står i fare for at ignorere de 'virkelige' begivenheder og for at nøjes med at beskæftige sig med den juridiske tænknings indre verden. ${ }^{8}$

Dansk retskultur er præget af den kontinentaleuropæiske erfaring med udviklingen af enevælde - fra 1660 til 1849 - før overgangen til et konstitutionelt monarki som følge af en række revolutionære bevægelser i Europa i 1848. Dansk retskultur er også præget af en patriarkalsk protestantisme, der var enerådende frem til 1849, og som fortsat var meget indflydelsesrig i de efterfølgende hundrede år. Den nationale demokratiske retskultur både den folkelige og den professionelle - fik gradvist udvidet deltagerne igennem en udvidelse af retten til uddannelse, valgret og bosætningsret. Efter 2. verdenskrig udfordredes de nationale retskulturer overalt, men især i den vestlige verden, ikke mindst pga. menneskerettighedernes stigende betydning. Samtidig blev de udfordret af de 'revolutionære' bevægelser i USA, Europa og store dele af resten af verden i 60erne - symboliseret ved årstallet 1968 - det såkaldte 'ungdomsoprør'. I USA kæmpede den sorte befolkning for civile og politiske rettigheder, og kvindebevægelse og ungdomsbevægelse ændrede i mange lande forholdet imellem køn (familie) og generationer, og hidtidige former for orden, myndigheder og institutioner oplevede store legitimitets- og autoritetstab. I Europa betød etableringen af Det Europæiske Økonomi- 
ske Fællesskab, der gradvis udvikledes til den ekspansive Europæiske Union et stigende pres på og en svækkelse af den nationale magt og dermed også en udfordring af den nationale retskulturs betydning. Presset er blevet forstærket betydeligt af globaliseringerne og den teknologiske IT-revolution. Göran Therborn beskriver i en artikel fra $2000 \mathrm{fem}$ samtidige globaliseringsdiskurser, nemlig den konkurrenceøkonomiske, den socialkritiske, diskursen om statens (im)potens, om kultur, og endelig om planetær økologi. ${ }^{9}$ Diskussionen om globalisering i de sidste år af det 20. århundrede har især fokuseret på den økonomiske globalisering. I denne sammenhæng er det imidlertid også diskussionen om de øvrige globaliseringsprocessers betydning, der trækkes på.

I slutningen af det 20. århundrede stod EU-medlemskabet i absolut fokus i den offentlige debat i Danmark indtil regeringsskiftet i 2001. Dette medlemskab svækkede både staten og den nationale retskulturs betydning. Regeringsskiftet, der af især Dansk Folkepartis medlemmer også betegnes Systemskiftet, flyttede fokus fra Danmarks omstridte økonomiske og kulturelle integration i den Europæiske Union og fra den begyndende globaliseringsdiskussion til et fokus på især muslimske indvandreres omstridte integration i Danmark. Det sidste er et af de områder, som lokale parlamenter i Europa og Danmark fortsat har en vis indflydelse på. Kulturkampen fremstilles som en national kamp indenfor de (svækkede) nationale grænser. Islams og andre religioners almene (social)kritiske holdning til økonomisk globalisering og global markedskapitalisme nedtones, og det samme gælder diskussionen om bæredygtighed og økologi. Samtidig raser globaliseringsdiskussionen og ambitionerne om at danskere skal kunne blive verdensmestre indenfor en lang række områder.

Retskulturelt står Danmark i et paradoks, hvor man på den ene side åbner op for markedskræfter og en langt mere markedsbåret og neo-liberaliseret retskultur, samtidig med at landet indadtil understreger en national-populistisk eksklusionspolitik, som ikke mindst får udtryk i en ekskluderende retorik og utallige løbende ændringer og stramninger af især udlændingelovgivningen. Store dele af den danske befolkning befinder sig fortsat - som en del andre europæiske befolkninger - i en slags 'globaliseringschok', både efter Murens fald og Tårnenes fald og måske også finanskrise(rne). Den har været relativt uforberedt på konsekvenserne af socialismens fald og de hurtige og voldsomme globaliseringer, der har svækket (velfærds)staterne. Betydelige dele af den vestlige verdens store ældre (vælger)befolkninger reagerer med frygt og afvisning, hvilket i Danmark især får udtryk igennem Dansk Folkepartis politik og populistiske kampagner. Muslimske indvandrere udgør en ganske lille del af be- folkningen i Danmark og Europa og dermed også en ganske lille del af vælgerbefolkningen, hvis interesser et nationalt majoritetsdemokrati ikke behøver at tillægge særlig stor vægt, og flygtninge har ingen intern politisk stemmevægt. Symbolsk repræsenterer de imidlertid en trussel imod den nationale - også retlige - enhedskultur og understreger at denne befinder sig i en transformationsfase.

Det er ikke første gang i nyere historie, at Danmark og ikke mindst Europa oplever system- og værdisammenbrud og dermed følgende politiske og retskulturelle ændringer. Op til 2. Verdenskrig blev dansk retskultur stærkt påvirket af tysk retskultur og tysk og tysksproget retsfilosofi. Den østrigsk-jødiske filosof Hans Kelsen med baggrund i det østrigske socialdemokrati påvirkede den danske jurist Alf Ross, der tidligt i sin karriere støttede Socialdemokratiet og hvis retstænkning kan beskrives som socialdemokratisk retsteori. Ross' påvirkning af den danske juridiske professions syn på ret og støtte til retspositivismen - især i København - varede ved til langt op i 70erne. Retspositivismens rolle er forblevet mere uomtvistet $i$ en dansk sammenhæng end $i$ en tysk primært pga. at værdisammenbruddet var langt stærkere i Tyskland end i Danmark.

Efter 1945 bliver dansk retskultur i stigende grad påvirket af krigens sejrherrer, og af amerikansk retskultur, både fordi mange nordiske og danske jurister har søgt og fortsat søger til USA, og fordi amerikansk retskultur igennem Hollywood i stigende grad påvirker den populære retskulturs forståelse af, hvor et retsvæsen fungerer også i Europa. Efter Murens fald og omkring årtusindskiftet sker der i de vestlige samfund gradvis et nyt skift i orienteringen. Udefra udfordres økonomi, politik og retskultur i stigende grad af de asiatiske økonomier, der gør sig stadigt stærkere gældende. Indefra udfordres de af demografiske udfordringer, der igen nødvendiggør indvandring. Samtidig sker der en vis konsolidering af allerede indvandrede grupper. Indvandrere med rødder i forskellige islamiske kulturer opleves i stigende grad som en provokation og til dels også en trussel af en (retlig) 'enhedskultur'. Disse udviklinger stiller spørgsmålstegn både ved de vestlige samfunds hidtil uantastede selvopfattelse som sekulære, og ved deres selvforståelse som økonomisk og kulturelt overlegne i verdenssamfundet. De giver også anledning til en række faktiske og symbolske konflikter. Konflikter om moskébyggerier illustrerer bl.a. at vestlige retskulturer, der bygger på en (romersk)/kristen/enevældig arv nu udfordres af Islam, som en anden af de monoteistiske religioner, der fortsat praktiserer en direkte forbindelse imellem religiøse og sekulære normer. Den stigende interesse (og ængstelse) for retskulturer med et eksplicit islæt af religiøsitet har ført til anvendelse af 
begreberne 'de-sekularisering' og 'post-sekularisering.' ${ }^{10}$ Begreberne angiver en fornyet refleksion over og betydning af en religiøs (kristen) arvs betydning i Europa også for retskulturerne. ${ }^{11}$

Retskulturer 'iscenesættes' rumligt. Som eksempel kan nævnes Københavns Byret (tidligere Københavns Rådhus), der er bygget efter bombardementet af København i 1807 i neoklassisk stil og har det græske tempel som forbillede. Arkitektur - og især monumentalarkitektur og symbolsk arkitektur - har altid været nært knyttet til både økonomisk og politisk magt, og bygningsværker demonstrerer og illustrerer derfor også nogle af de ændringer som et samfund og dets retskultur(er) undergår.

\section{Monumentalarkitektur: sakral kultur og con- tainerkultur}

Professor i kunsthistorie i Oslo, Kari Hoel udgav i 2008 en bog med titlen Monumentalarkitektur i Oslo. Fra kongens slott til kunnskapens tempel. Titlen illustrerer hvordan magtens arkitektoniske udtryk skifter, men også hvordan de fortsat forlenes med en sakral aura. Hoel skriver at begrebet monumental i de sidste tiår $\mathrm{i}$ syttenhundredetallet blev en accepteret betegnelse på et fritstående bygningsværk af dominerende karakter. „Etter den tid ble monumentalarkitekturens oppgave à synliggjore samfunnets offisielle vurderinger. "12 En del litteratur om monumentalarkitektur vedrører Mellemøsten i forhistorisk tid, hvor meget byggeri havde monumental karakter. ${ }^{13}$

Nationalmuseet arbejder i øjeblikket på det der kaldes "JELLINGPROJEKTET - et kongeligt monument $i$ dansk og europaisk belysning. "Her tænkes monumentalitet i klassisk forstand - som stort og unikt og udtryk for dominerende værdier. Af beskrivelsen fremgår det tydeligt, at monumenter kan undersøges - og tolkes - som eksempler på og illustration af forandring af trosformer, magtformer, samfund og verdensbilleder. Projektet beskrives på nettet på følgende måde:

„Projektet tager udgangspunkt i Jellingmonumenternes enestående karakter. På et og samme sted findes her et anlæg, hvis enkelte dele markerer både overgangen fra hedenskab til kristendom og etableringen af den danske kongemagt. Monumenterne er derfor oplagte som udgangspunkt for en undersøgelse af den transformering af det danske samfund, der fandt sted i vikingetiden og den tidlige middelalder under stærk påvirkning af især det Ottonske kejserrige. Kontakten mod syd bragte ikke blot den kristne kirkes verdensbillede, men også nye sociale og politiske strukturer til Danmark." ${ }^{\text {"14 }}$

Der er næppe nogen tvivl om, at interessen for det nationale monument som Jellingkomplekset betragtes som, også må ses i lyset af nutidens globale forandringer, og at projektet har til hensigt at bidrage til en kontekstualise- ring og forståelse af samtidsforandringer. Når man undersøger dagens monumentalarkitektur kan man derfor have både overgange, værdiskift og transformationer, der er påvirkede udefra, for øje.

Et af de byggerier, der omtales i Hoels pragtværk om monumentalbyggeri i Oslo er Sankt Hallvard Kirke og Kloster på Enerhaugen i Oslo, tegnet af en af de mest betydningsfulde norske arkitekter i det 20. århundrede, Kjell Lund. Han har i flere omgange arbejdet med sakral arkitektur især i byggeprojekter for den katolske kirke i Norge, og har også i flere omgange skrevet om dette. I 1995 udgav han en artikel "I narheden af det sakrale rom", hvor han skrev:

„Målsettingen for det sakrale rommets arkitektur er å tjene og støtte liturgien under deltagelse i de rituelle handlinger, men også å løfte os ut av våre konvensjoner og fristille for utvidet erkjennelse av å være til. Dette gjelder umiddelbart for sakrale bygninger uansett religion og trosretninger og gjennom alle tider[...]. Kunstog arkitekturhistorien dokumenterer at det finnes felles formale elementer i sakrale bygninger og rom, uavhengig av stilarter og bekjennelse. Uansett om vi er oss det bevist eller ikke som kunstner eller arkitekt under den kreative prosessen, følger vi i fotefarene til dem som gikk foran. ${ }^{\text {"15 }}$

Hvis man ser på operabyggerier som 'kvasi-sakrale'16, så kan man også se dem som rum, der under deltagelse af rituelle handlinger - dyrkelse af kunst - løfter ud af konventioner og bidrager til udvidet erkendelse. De hører i egen selvforståelse hjemme i en vestlig sekulær kultur - 'tyrkere går ikke i operaen' ${ }^{17}$ - og de betjener sig af et transnationalt repertoire - ofte influeret af tysk og italiensk musikkultur i det 18. og 19. århundrede. ${ }^{18}$

Operabyggeriet i København er et monumentalbyggeri i klassisk forstand, der måske kan siges at markere overgangen fra 'sekulær lutheranisme'19 til post-sekulær globalisering, og som også indikerer en transformering af det danske samfund væk fra et klassedelt industrisamfund imod et samfund, der er langt stærkere påvirket af informationsteknologi, politisk-juridisk status og økonomiske privilegier forbundet med filosofisk/religiøse orienteringer.

Et essay af en tysk filosof, Hannes Böhringer, ansat ved en tysk, kunsthistorisk institution omtaler containeren i forhold til monumentalarkitektur. Containeren er provisorisk arkitektur, hvis form ikke længere retter sig efter indholdet - som kan være alt muligt - men efter standardmål, der gør den kompatibel og til at stable - en neutral form eller nul-komposition, en ligegyldighedens magnet, hvor forskellen mellem det indre og det ydre er radikalt indifferent. Den er allerede bygget, og kan derfor kun dekoreres - som en lang række containere blev det i Københavns havn, da København i 1996 var europæisk 
kulturby. Ifølge Böhringers essay er det ikke kun store og storartede byggerier, der er monumentalarkitektur, men også udsmykning og dekorationer, ornamenter på almindelige bygninger, der ikke ser ud af noget. Monumentalarkitektur er ifølge ham 'støttebyggeri for erindringen' - et memento om ikke at glemme at 'urhytten verden allerede er skabt'. ${ }^{20}$ Denne 'minimalistiske' opfattelse af monumentalarkitektur giver måske rum for en tænkning i fleksibilitet og udskiftelighed i en postmoderne og postnational retskultur. - Denne kunne ses som bestående af udskiftelige enheder og elementer, der kan gives en slags lokal dekoration. København har ligesom de fleste europæiske storbyer allerede en række moskeer - ofte placeret $\mathrm{i}$ tidligere industribygninger og ofte i nedslidte kvarterer. - En slags 'container-moskeer' kunne man kalde dem.

\section{Amalienborg-aksen - et symbol på enevældens retskultur?}

Marmorkirken - for og efter religionsfriheden

Byggeriet af starten på Amalienborg-aksen, den stort anlagte Frederikskirke skulle markere kongeslægtens, oldenborgernes 300 år i kongehuset, og Frederik den 5 nedlagde grundstenen i Frederiksstaden i 1749 - knap 90 år efter indførelsen af Enevælden i 1660. Kirken var oprindelig tegnet af arkitekten Nicolai Eigtved og skulle være højdepunktet i Frederiksstaden. Eigtved døde imidlertid få år efter, og den efterfølgende arkitekt Jardin gjorde byggeriet så dyrt, at det blev opgivet. I omkring 100 år stod kirken som en ruin indtil finans- og industrimanden C.F. Tietgen (1829-1901) i 1874 købte kirkepladsen, inklusive ruinen af staten. Efter enevældens ophør og vedtagelsen af grundloven havde staten i 1849 overtaget ejerskabet fra kongehuset med det formål at videreføre byggeriet. Staten magtede imidlertid ikke at gennemføre byggeriet, men gjorde dets færdiggørelse til betingelse for salget af området til Tietgen. Byggeriet skulle have været gjort færdigt på 10 år, men det tog Tietgen 20 år. Kirkens bygningshistorie afspejler således ikke blot en enevældig retskultur, men også transformationen til et borgerligt demokrati og et klassesamfund i sin vorden med skabelse af organisationer der repræsenterede industrisamfundets vigtigste kræfter, arbejdsgivere og arbejdere.

Byggeriet af Amalienborg som private palæer blev påbegyndt omkring 1750. Det blev først delvist residens for kongefamilien efter at Christiansborg var brændt i 1794. Frederikskirkens placering på Amalienborg-aksen understreger alligevel det historisk nære forhold imellem kongemagt og den protestantiske kirke, hvor kongen var kirkens overhoved, og hvor befolkningen ikke havde religionsfrihed. Deres tro var bestemt af monarkens. ${ }^{21}$

Katolikker, jøder, jesuitter og herrnhuter kunne derfor ikke uden videre bosætte sig i landet. Forskellige af kongerigets monarker havde imidlertid efter reformationen grundlagt en række 'religiøse fristeder', for at tiltrække entreprenante indvandrere, der kunne bidrage til rigets velstand. Glückstadt i Hertugdømmet Holsten (nær Hamburg) blev grundlagt i 1617 af Chr. IV, der havde ambitioner om at gøre byen til en konkurrent til Hamburg. Han gav byen handelsprivilegier og religionsfrihed, og etablerede den første jødiske kirkegård i det, der i dag er Tyskland. Frederiksstad i hertugdømmet Slesvig blev i 1600-tallet bygget af tilkaldte nederlandske religiøse flygtninge, som blev tilkaldt af den daværende gottorpske hertug Frederik den 3. Den blev kaldt tolerancebyen. Fredericia blev grundlagt i 1650 af kong Frederik III. I 1682 gav Chr. V byen religionsfrihed, frihavnsret og asylret. Men disse eksempler på religiøs tolerance var få og små og lå fjernt fra hovedstaden. Ved plakat af 9. september 1726 blev det bestemt, at ingen jøde måtte nedsætte sig i København, uden at han ejede en sum af 1000 rigsdaler, eller at han forpligtede sig til inden en vis bestemt tid af egne midler at opføre et hus af en bestemt størrelse eller at indrette manufakturer for visse varer. I 1780 var der lidt under 50 jødiske familier i København. ${ }^{22}$ Den københavnske og det meste af kongerigets befolknings kendskab til andre trosformer og mennesker af anden tro har således langt op i det 19. og 20. århundrede været særdeles begrænset.

\section{Operaen - og den protestantiske etik}

Amalienborg-aksen demonstrer både enevældens - efterhånden svækkede - magt og industrimagnaternes stadigt øgede magt fra det 19. århundrede. Både Tietgen og A.P. Møller familien har været repræsentanter for en både national og protestantisk etik, samtidig med at begge erhvervsimperier har været del af og tjent på det 19. og 20. århundredes globaliseringsbevægelser.

Som eksempel på den nationale orientering kan nævnes, at A.P. Møller Fonden i 2008 indviede det andet danske gymnasium syd for grænsen i byen Slesvig. A.P. Møller-skolen er fuldt finansieret af fonden, og selvom oplysninger om omkostningerne ved byggeriet ikke er offentligt tilgængelige, er byggeriet klart et meget bekosteligt prestigebyggeri, der demonstrerer både giverens $ø$ konomiske styrke og nationale tilknytning. A.P. Møller Fonden har givet betydelige beløb til byggeri og istandsættelser af uddannelsesinstitutioner og kirker i Sydslesvig, ${ }^{23}$

Skal man bygge et monumentalbyggeri $i$ København i begyndelsen af det 21. århundrede, er det ikke oplagt at bygge hverken skole eller protestantisk kirke. Her er det kulturforbrugerne, der er blevet tilgodeset. Operakulturen er en elitekultur, der i slutningen af det sekulariserede 20. århundrede har undergået en vis demokratise- 
ring blandt andet via TV-udsendelser og 'De tre tenorers' optræden ved World Cup i fodbold - første gang i Rom i 1990. En lang række europæiske byer har indenfor de sidste 20-30 år bygget operaer og musikteatre: Amsterdam i 1986, Paris i 1989, Helsinki og Göteborg i 1994 og Tokyo i 1997, ligesom der er ambitiøse planer om operabyggeri i Skt. Petersborg. ${ }^{24}$ Oslo indviede en opera i april 2008, der beskrives som det største byggeri i Norge efter afslutningen af byggeriet af Nidarosdomkirken i Trondheim i det 14 . århundrede. ${ }^{25}$ Tysklands første opera blev bygget i Hamburg i 1678 og Hamburg påbegyndte i 2007 et meget stort prestigebyggeri af en koncertbygning (Elbphilharmonie) som en om- og udbygning af et tidligere pakhus, der i øjeblikket ser ud til at blive mere end tre gange så dyrt som oprindelig planlagt. De fleste af disse byggerier sker i protestantiske samfund - eller i sekulære og ikke-kristne samfund, hvor kulturen (den tidligere 'fin-kultur', der til en vis grad er blevet demokratiseret) måske får en slags 'erstatningsfunktion' som samlingspunkt og erkendelses- og tolkningsramme for en del af senmodernitetens udvidede elite.

Skibsreder Møller, hvis hovedindtægter i de senere år stammer fra olieudvinding og container-virksomhed, der om noget er knyttet til globaliseringen, har således også i byggeriet af operaen været involveret $\mathrm{i}$ en global konkurrence om at demonstrere prestige og udvikle 'oplevelsesøkonomi' i en periode, hvor kunst og kultur er blevet 'merkantiliserede'. 26

I sin bog om 'Operaen på Dokøen' beskriver arkitekten Anne-Louise Sommer operabygninger på mange forskellige måder - som 'kunsttempel', ${ }^{27}$ som vartegn, ${ }^{28}$ som 'teaterkatedral', ${ }^{29}$ eller som en 'slags civilisationens verdslige katedral'. ${ }^{30}$ Disse beskrivelser antyder både den monumentale og den sakrale dimension af disse byggerier. Måske kunne man i dag kalde dem bygninger, der giver 'mening for middelklassen' en slags 'middelklassens eksistentielle templer' - rum, der giver rituelle rammer for en voksende klasse, hvis orientering primært har været orienteret imod materielt forbrug, men som i stigende grad også efterspørger et eksistentielt, kulturelt indhold i en post-materiel, de-sekulariseret epoke, hvor identitet har stået højt på dagsordenen.

Bygningerne er arkitektonisk blevet demokratiserede, men operaer og operaforestillinger er kostbare fænomener, og Københavns opera, der anslås til at have kostet 2,5 mia kr. skulle være en af verdens hidtil dyreste. ${ }^{31}$ Her er klart tale om kostbart prestigebyggeri, med forestillinger, der ikke uden videre er tilgængelige for enhver pengepung. I kapitlet 'Prestigebyggeri og offentligt rum' skriver Anne-Louise Sommer, at det er et velkendt fænomen, at enevældige herskere igennem tiderne har understreget deres magt netop igennem 'arkitektoniske pragtud- foldelser'. ${ }^{32}$ De fleste kulturbyggerier i Europa i det 20. århundrede har ifølge hende været stærkt påvirkede af konflikter i relation til de politiske beslutningsprocesser. I forhold til Operaen i København betød det forhold, at bygningen var en donation fra privat fond, at debatten ikke har haft samme grad af åbenhed som ellers ved byggerier af den art.

„I den forstand giver historien snarere genklang fra fjerne tider, hvor det var mæcenen, der enevældigt projekterede og udkastede retningslinjer for forløbet og resultatet." ${ }^{\text {"33 }}$

Så aksen er måske gået fra at symbolisere enevældig monarkisk retskultur til at symbolisere enevældig mæcen-kultur og markedsretskultur. Fra 1980erne har det især har været advokatbranchen, der har udgjort en prestigefyldt del af den juridiske profession. Det er den del af professionen, der især har medvirket til fusioner og fungeret som redskaber for globaliseringerne. De høje lønniveauer, der er knyttet til markeds(rets)kulturen (herunder til finanssektoren) vidner om at det ikke længere er et nationalt arbejdsmarked og et nationalt økonomisk niveau, der udgør målestokken for mæcenkulturen.

\section{IV. 'Nordvest-aksen' - et symbol på retskultur un- der globalisering?}

Langt de fleste moskeer i København er placerede på Nørrebro ifølge en adresseliste på nettet fra 2006. Vesterbroadresser kommer ind på andenpladsen, og Amageradresser på en tredjeplads. ${ }^{34}$

Hvis man ser på moskeernes topografi, er det tankevækkende, at både det retablerede Ungdomshus og Det Islamiske Trossamfund, der driver Tauba-moskeen for sunni-muslimer i København (majoriteten blandt den lokale muslimske minoritet) har adresser på Dortheavej i Københavns Nordvestkvarter - på hver sin side af Tomsgårdsvej. Begge fællesskaber har hjemme i bygninger, der tidligere har tjent andre formål, og som nu er transformeret til kult- og kulturformål. Bygningerne ligger i og i umiddelbar nærhed af et kvarter, der historisk har været beboet af og forbundet med den mest aktive del af den københavnske arbejderklasse og med senere politiske bevægelser. Ombygningen af et andet islamisk kulturcenter til en shiitisk moske på Vibevej - sker på samme topografiske 'akse.' 'Nordvest-aksen', som jeg her vil kalde den, kan i min optik ses som en slags post-national globaliseringsakse af grupper, der i lokal og national sammenhæng er minoriteter, men ikke nødvendigvis er det $\mathrm{i}$ en global sammenhæng. ${ }^{35}$ Disse gruppe- og generationsfællesskaber om religiøs kultur og ungdomskultur er begge svagt - men forskelligt - repræsenterede i det nationale demokrati og står begge svagt i markedskulturen i dag. I fremtiden kan deres position imidlertid blive 
styrket økonomisk pga at de bliver meget nødvendige for lokal- og nationalsamfundets velfærd. I dag står de i delvis modsætning til en nationalt orienteret demokratisk kultur og en globalt orienteret markedskultur. Operaen befinder sig primært på markedsaksen og servicerer fsv også en minoritet, men en privilegeret sådan, mens moskeerne og ungdomshuset befinder sig på en noget mere markedskritisk akse. 'Nordvest-aksen' står svagt både i forhold til nationalt demokrati og globalt marked, men ikke i forhold til religiøse og ideelle fællesskaber.

\section{Ungdomskultur, bykultur og civil ulydighed}

Byggeriet af operaen og især processen er blevet kritiseret for manglende demokrati, åbenhed og transparens alt sammen elementer, der også er karakteristiske for en markedskultur. I europæiske storbyer er det ikke mindst ungdomsbevægelser, der kritiserer og modarbejder den markedsbårne 'gentrificering' af byerne og kommercialiseringen af kulturen, som operabyggeriet også kan siges at være udtryk for, men de er foreløbig ikke særlig stærke og har ikke fået særlig stor offentlig opmærksomhed. Et eksempel er bevægelsen 'Recht auf Stadt' - 'ret til/i by' der bl.a. i Hamborg (og Lund) har gennemført demonstrationer imod, at byen kun er tilgængelig for indbyggere med betydelige indkomster. ${ }^{36}$ Med Europas demografiske sammensætning udgør unge vælgere en forholdsvis begrænset gruppe, og den demokratiske retskultur kan derfor siges i sin nuværende form at udvikle og støtte en gerontokratisk kultur, hvor en aldrende befolknings interesser og bekymringer tilgodeses i højere grad end en ung vælgerbefolknings interesser. Den yngre del af befolkningen vil i løbet af de kommende tiår skulle bære betydelige samfundsmæssige forsørgerbyrder, samtidig med at de kan få vanskeligt ved at få demokratisk indflydelse som vælgere. Dette forhold kan medvirke til, at der fra denne gruppes side bliver stillet spørgsmål ved legitimiteten af demokratierne i den form, som Europa har kendt dem i slutningen af det 20 . århundrede. ${ }^{37} \mathrm{I}$ processen mod en transformering af det danske (og de europæiske) samfund og en udvikling af nye politiske og sociale strukturer og kulturer har der hidtil især været medieopmærksomhed på en udvikling af en højrepopulisme med stigende indflydelse på national politik. Det kan måske tænkes, at der i nærmeste fremtid kan opstå et pres for at 'demokratisere demokratiet' også fra andre gruppers side, så de grupper, der i dag har begrænset politisk indflydelse får nye muligheder for indflydelse, der bedre modsvarer deres bidrag til samfundsøkonomi og velfærd.

De konflikter, der primært kommer op i medierne vedrører adgang til fysiske mødesteder for især byernes unge (i Danmark Ungdomshuset) og unges adgang til og anvendelse af kulturelle goder (ikke mindst musik og billeder). Nogle af disse aktiviteter betegnes som 'pirateri' og aktivisterne som pirater. Fællesskaberne får til tider udtryk i form af temporære og mobile 'piratfester'. Andre aktiviteter, som en del (men langt fra udelukkende) unge har engageret sig i beskrives som 'civil ulydighed', som for eksempel aktionerne i forbindelse med Kirkeasylet i Brorsonskirken i 2009. Der er i alle tilfælde tale om omstridte aktiviteter. Og betegnelserne antyder en juridisk gråzone i forhold til forståelsen af ejendom, ret og moral $i$ et samfund i transformation.

Konflikter i forhold til (indflydelsesrige dele af) en fremtidig forsørgergeneration kan forventes at blive mødt med en vis ambivalens fra både politikere og medier. Måske er det derfor, at de politiske konsekvenser af disse strukturelle ændringer af samfund og retskultur diskuteres ret sjældent i offentligheden.

\section{'Stormoske' og frygtens retskultur}

Byggeri af moskeer rundt omkring i Europa og af en stormoske i København har derimod, som det er bekendt og som det beskrives grundigt af Sune Lægaards artikel ${ }^{38}$, tiltrukket sig betydelig opmærksomhed. Dette hænger formentlig både sammen med mediekriterier om sensation, konflikt og problemer, der sikrer seertal, sælger aviser og giver adgang til stemmer. Det hænger også sammen med den globalisering, der har medført usikkerhed overfor hastige forandringer og som foreløbig har ført til en generel styrkelse af højrepopulismen i Europa og Danmark. Og det har sammenhæng med det allerede nævnte forhold, at muslimer i Europa fortsat udgør en ret lille gruppe uden betydelig politisk stemmevægt eller omfattende økonomisk magt eller effektive organiseringer.

Fremskridtspartiets Kim Behnke, udtalte for mere end tyve år siden at 'vi' har ikke nogen ret lang tradition for at andre religioner er synlige i gadebilledet, og der var efter hans mening heller ikke behov for at ændre på denne tradition. ${ }^{39}$ Denne tradition for religiøs enhed går tilbage til enevælden, og jeg vil påstå at også Dansk Folkepartis understregning af religiøs enhed som et dansk fænomen går tilbage til en enevældig retskultur.

Moskebyggeriet er i den sidste fase især fra Dansk Folkepartis side blevet beskrevet som et byggeri af en 'stormoske' og plakaterne viser et sandt monumentalbyggeri - formentlig den blå moske i Istanbul - til lejligheden forsynet med drabelige sværd og halvmåner. Ombygningen af det islamiske kulturcenter på Vibevej forstørres i en skrækvision op til et egentligt monumentalbyggeri, der afvises som et både uacceptabelt og udemokratisk (sakralt) byggeri. De konkrete planer for moskebyggeriet ser ganske vist ikke ud til at være i en størrelsesorden, så det kan betegnes som monumentalt. Men ved at betegne bygningsværket som 'stort' spilles der på frygten for at blive 
løbet over ende af ustyrlige kræfter - være sig religiøse, befolkningsmæssige eller politiske. Der spilles her på en 'frygtens retskultur,' som har udgjort en væsentlig del af den politiske retorik i begyndelsen af det 21. århundrede.

Retsfilosoffen Peter Højlund skriver i sin lille bog, Frygtens ret, at bogen er blevet til på baggrund af en bekymring:

\section{„Min bekymring består i, at vi på det retlige område i dagens samfund ser tegn på en stadig mere ekskluderende, autoritær, fremmedgørende og fjendtlig tendens i lovgivning, domme og administrative afgørelser. Fremvæksten af en decideret frygtkultur synes de seneste 10 år at have transformeret dele af vor ret og retsanven- delse i sådan retning." ${ }^{40}$}

Denne tendens er særlig stærk i forhold til muslimske indvandrere, men jeg tror at det er på sin plads også at gøre opmærksom på, at den rammer bredere og at især unge - herunder selvfølgelig også indvandrerunge - rammes ganske betydeligt. Peter Højlund skriver at de sikkerhedsforanstaltninger, som frygten giver anledning til, 'omstrukturerer det fysiske rum arkitektonisk, teknologisk og juridisk. ${ }^{311}$ Han diskuterer eksempler på konsekvenser af 'frygtens ret', bl.a. de såkaldte visitationszoner, der som hovedregel etableres i større byer, hvor der fx afholdes koncerter og større møder; den såkaldte 'lømmelpakke', der som navnet antyder også retter sig imod unge, og som giver politiet ret til at anholde politiske demonstranter administrativt (som ved COP 15 demonstrationerne i december 2009); og ikke mindst udlændingelovgivningen og dens hyppige ændringer. I afslutningen skriver han, at han ikke argumenterer for mere jura, men at hans indvending går på

\section{„at den demokratiske retskultur fortrænges og erstattes af et miskmask af uigennemskuelige styringsformer med økonomisk ressourceregule- ring som dynamo, og at lovgivningen forstået som en kompliceret tekst til brug for velfungerende samfundsinstitutioner, ikke længere har politisk interesse som sådan. “"42}

Peter Højlund skriver efter min vurdering primært om det som Lawrence Friedman kalder den interne retskultur eller professionskulturen, som dog i denne udviklingsproces spiller tæt sammen med en folkelig - og frygtsom - majoritetsretskultur.

\section{Postnational retskultur og demokratiudvikling i det 21. århundrede}

Marianne Horsdal, der har forsket i livshistorier, og som nu er professor ved Institut for Filosofi, Pædagogik og Religionsstudier ved Syddansk Universitet i Odense, skriver i en artikel om 'Demokratisk medborgerskab og biografisk læring' om Europarådets 'Budapest erklæring'. Denne erklæring fra 1999 fremhæver, at uddannelse i demokratisk medborgerskab „udgør en livslang læringserfaring og en deltagelsesproces, der udvikles i forskellige kontekster. “43 En sådan uddannelse skal iflg Horsdals omtale af deklarationen gøre mænd og kvinder i stand til at tage aktivt del i det offentlige liv, sigte mod at bibringe en kultur baseret på menneskerettighederne, udruste mennesker til at leve $i$ et multikulturelt samfund og til at kunne forholde sig vidende, fornuftigt, tolerant og moralsk til forskellighed, styrke social sammenhængskraft, fælles forståelse og solidaritet og skal omfatte alle aldersgrupper og alle sektorer i samfundet.

Demokratisk dannelse kræver et opgør og en transformation af tidligere forståelser og traditioner:

\section{„En rekonfigureret ny forståelse indebærer imidlertid en foreløbig dekonstruktion af tidligere forståelser, en foreløbig dekonstruktion af mening, som mennesker, der ikke bryder sig om forandrin- ger, ofte afviser. I stedet klynger de sig til gamle opfattelser i ønsket om kontrol eller sikkerhed."“4}

'Mennesker, der ikke bryder sig om forandringer' er måske de fleste. Den europæiske Union domineres i dag af medlemslande med konservative eller centrum-højre regeringer. Både 'flertal' og 'mindretal' ønsker kontrol og sikkerhed, der ser ud til at være nogle af de centrale værdier i det 21. århundredes vestlige samfund for indeværende, som derfor også får stor indflydelse på både folkelige og professionelle retskulturer. Men Marianne Horsdal skriver også, at hendes analyse af livshistorier viser, at de som kun har fulgt ét spor er de mest sårbare, og at de har større risiko for at bryde sammen, når de konfronteres med krav om fleksibilitet. ${ }^{45}$ Hun peger på betydningen af 'poly-kontekstuel dannelse', der finder sted i mange forskellige sammenhænge. Man kunne tænke sig, at både operaer, kirker, moskeer samt ungdomshuse og uddannelsesinstitutioner kunne udgøre kontekster for en sådan poly-kontekstuel dannelse - og at jo flere af disse dannelsessteder, den enkelte har adgang til, jo bedre beskyttet mod sammenbrud er både den enkelte og fællesskaberne. Iflg. den norske arkitekt Kjell Lund, der er citeret ovenfor er et af formålet med sakrale rum at 'fristille for utvidet erkjennelse av å være til'. Denne ud- 
videde erkendelse er der stærkt behov for i en globaliseret transformationsproces.

En udvidet demokratisk dannelses- og erkendelsesproces vil i det 21. århundredes globaliserede verden ske og skulle ske i mange sammenhænge. I begyndelsen af det 20. århundrede, før kvinder og arbejdere fik stemmeret, foregik der en lang række kampe imellem arbejdere og arbejdsgivere, før der blev udviklet nye retsformer i form af den kollektive aftaler, nye institutioner i form af $\mathrm{fx}$ Arbejdsretten og Faglig Voldgift, og en retskultur, der kunne sikre fred og fastslå og fastholde fredspligt i forholdet mellem parterne på arbejdsmarkedet og i samfundet. Også i begyndelsen af det 21. århundrede er der - både af hensyn til fremtidig velfærd og sikkerhed - behov for at videreudvikle den demokratiske retskultur til en kultur, der i langt højere grad formår fredeligt at inddrage grupper, der for øjeblikket står yderligt svagt og yderligt. Der er behov for at demokratisere den globale retskultur, som i øjeblikket præges af mæcenkultur og markedsmagt, samtidig med at der er behov for at globalisere og åbne den nationale retskultur, som i øjeblikket præges af frygtkultur og afmagt. Både opera og 'stormoske' er arkitektoniske eksempler på institutioner, der potentielt kan udgøre rum for erkendelse og transformation i samfund, der er under forandringspres indefra og udefra, og oppefra og nedefra og som er i færd med at danne sig nye billeder af verden og verdenssamfund. Hvis der skal skabes attraktive forhold for flest mulige af alle dem, der deltager i og bidrager til disse kulturer og deres overlevelse og videreudvikling på kort og langt sigt, forudsætter det at alle tilpasser sig de ændrede forhold. Det gælder både indvandrere, omvandrere og de hjemmefødinge, der indtil videre udgør de formelle flertal i dagens småstater. En tilbagevending til en enevældig retskultur er næppe vejen frem på nogen af akserne. Der er behov for at vestlige 'atlantisk-europæiske' retskulturer - inklusive den danske - besinder sig på, hvordan de kan indgå i en planetarisk retskultur og hvilke konstruktive bidrag de kan komme med til udviklingen af verdenssamfundet og en verdensret. ${ }^{46}$ Både en planetarisk retskultur og en verdensret den må i sagens natur være ganske rummelig og inklusiv og kan ikke bero på nogen 'overstat'.

\section{Noter}

1. Tak til den anonyme referee for meget grundige og inspirerende vurderinger og overvejelser.

2. Francis Hagerup: Ret og Kultur i Det Nittende Aarhundrede. I i en serie om 'Det Nittende Aarhundrede Skildret af Nordiske Videnskabsmænd' redigeret af Aage Friis. Gyldendalske Boghandel, Nordisk Forlag, s.1
3. Gustav Radbruch, Gesetzliches Unrecht und übergesetzliches Recht. Første gang offentliggjort i Süddeutsche Juristenzeitung 1946 , s. $105-108$. http://www.digizeitschriften.de/main/dms/ img/\#navi (2010-09-12)

4. Gustav Radbruch, Der Geist des englischen Rechts. Vandenhoeck \& Ruprecht, Göttingen 1956, s.5 \& 8

5. Radbruch 1956, s.31

6. Lawrence M. Friedman, 'Legal Culture and Social Development', in Law \& Society Review, Vol. 4, No. 1 (1969) s. 29-44

7. L. Friedman, 'The Concept of Legal Culture: A Reply', I David Nelken (ed) Comparing Legal Cultures. Aldershot: Dartmouth, 1997, s. 34

8. Se også Jo Carillo, Links and Choices: Popular Legal Culture in the Work of Lawrence M. Friedman. In Southern California Interdisciplinary Law Journal, Vol 17:1, 2007

9. Göran Therborn (2000): Globalizations: Dimensions, Historical Waves, Regional Effects, Normative Governance. International Sociology, Vol 15, No. 2, June 2000

10. I december 2010 afholdtes et ph.d. seminar på RUC med titlen: Post-secular conditions? Challenges to citizenship, democracy, law and social cohesion

11. Se f.eks. diskussionerne i Lisbet Christoffersen, Hans Raun Iversen, Hanne Petersen \& Margit Warburg (red), Religion in the 21st Century. Challenges and Transformations. Ashgate 2010, og i Lisbet Christoffersen et al (red): Law \& Religion in the 21st Century Nordic Perspectives. DJØF-publishing 2010

12. Kari Hoel, Fra Kongens Slott til Kunnskapens Tempel. Vigmostad \& Bjørke AS, Bergen, 2008. Operabyggeriet behandles ikke i dette værk, s.12

13. M. van Ess/ Th. Weber (Hrsg.), Baalbek. Im Bann römischer Monumentalarchitektur. Verlag Philipp von Zabern, Mainz am Rhein, 1999

14. Fremhævelser her - se http://www.natmus.dk/graphics/Pressefoto/ Jelling/Jellingprojektet.pdf

15. Her citeret fra Kari Hoel, Monumentalarkitektur i Oslo, 2008, s. 279

16. Se referencerne til Anne Sommer, Operaen på Dokøen, 2007, i afsnittet nedenfor om „Operaen - den protestantiske etik“.

17. Elisabeth Beck-Gernsheim, „Ein Türke geht nicht in die Oper“ was Deutsche über Türken wissen. I Caroline Y. Robertson-von Trotha (red), Kultur und Gerechtigkeit., Nomos, Baden-Baden, 2007, s. 113-122

18. I begyndelsen af det 21. århundrede har mange operaer - inklusive Københavns - sat Wagners monumentalværk Nibelungen Ringen op - skrevet i midten af det 19. århundrede og præget af sociale og politiske revolutioner, industrisamfundets fremvækst og gamle ordners undergang.

19. Et udtryk brugt af Anders Berg-Sørensen, se hans artikel, The Politics of Lutheran Secularism: Reiterating Secularism in the Wake of the Cartoon Crisis. I Lisbet Christoffersen, Hans Raun Iversen, Hanne Petersen \& Margit Warburg, Religion in the 21st Century. Challenges and Transformations. Ashgate 2010, s. 207-214

20. Hannes Böhringer, Orgel und Container - Merve Verlag Berlin 1993

21 Dette princip kaldes cujus regio, eius religio. Den, der regerer, bestemmer religionen.

22 Kilde: artiklen Jøder i Danmark på Wikipedia, opslag 31.8.2010

23 Jfr. oplysninger på Fondens hjemmeside. Jeg besøgte i sommeren 2010 gymnasiet, hvis hal er bygget op som et teater udsmykket med et 'tellurium' - en model af jorden, månen, solen og de øvrige planeter - af Olafur Eliasson - med umiskendelig lighed med lamperne i operahuset i København. 
24 Anne-Louise Sommer, Operaen på Dokøen, Gyldendal 2005, s. 18 (Engelsk udgave: The Copenhagen Opera House, Gyldendal 2007 - jeg citerer i det følgende fra begge værker)

25 http://en.wikipedia.org/wiki/Oslo_Opera_House (2010-09-12)

26 Sommer 2005, s.31

27 Sommer 2007, s.19 (i den danske udgave tales der om at tilbringe en dag 'i kunstens tegn').

28 Sommer 2005 - om operaen i Sydney, s.39. Koncerthuset i Hamburg markedsføres også som et vartegn for byen.

29 Sommer 2005 - om Grand Theatre i Bordeaux fra 1780 bygget i italiensk stil, s.54

30 Sommer 2005 - med citat af en beskrivelse af kunstkritikeren Théophile Gautiers beskrivelse af operaen i Paris i 1863, s.60

31 Iflg. artiklen Copenhagen Opera House http://en.wikipedia.org/ wiki/Copenhagen_Opera_House (31.9.2010)

Operaen i Oslo har været dyrere, og det bliver operaen i Hamborg formentlig også.

32 Sommer, s. 40

33 Sommer, s.46

34 http://www.islamstudie.dk/aa_moskeer.htm - listen er underskrevet Aminah Tønnsen, marts 2006 (sidst besøgt 2010-09-06)

35 Se bl.a. Hanne Petersen, Beyond National Majority/Minority Dichotomies. Towards Legal Traditions \& Religions of World Society - A Local Example. I Lisbet Christoffersen, Kjell Åke Modéer \& Svend Andersen, Law \& Religion in the 21st Century - Nordic Perspectives. DJØF Publishing, 2010, s.321-344
36 http://www.rechtaufstadt.net/recht-auf-stadt

37 Se fx Gritt Bykilde, Når unge udfordrer demokratiet, Forlaget Samfundslitteratur 2000

38 Se dette nummer af Politik

39 Folketingstidende tillæg A:1988 - her citeret efter Brian Arly Jacobsens artikel i dette nr.

40 Peter Højlund, Frygtens ret, Hans Reitzels Forlag, 2010 s.17

41 Højlund, s. 75

42 Højlund, s. 139

43 Marianne Horsdal, Demokratisk medborgerskab og biografisk læring. I Ove Korsgaard (red), Medborgerskab, identitet og demokratisk dannelse. Danmarks Pædagogiske Universitets Forlag, 2005, s. 118

44 Samme, s.129

45 Samme, s. 131

46 Den tyske retshistoriske professor, Franz Wieacker brugte allerede i 1985 udtrykket ,planetarisk retskultur' i en forelæsning Voraussetzungen europäischer Rechtskultur. Bursfelder Universitätsreden herausgegeben von Lothar Perlitt, Abt von Bursfelde, Verlag Göttinger Tageblatt GmbH \& Co, 1985, 31 s. Wieacker bruger også udtrykket 'atlantisk-europæiske' retskulturer, som er dem, jeg altovervejende omtaler i artiklens første afsnit.

Den amerikanske retshistoriske professor, Harold J. Berman brugte i 1995 udtrykket ,world law' i en lille artikel. ,The Role of International Law in the 21st Century: World Law, Fordham International Law Journal, 1617-1621 